\title{
Study on Contents of Extracurricular Moral Education in U.S. Ivy League
}

\author{
Bo Lu \\ Yangtze University College of Engineering and Technology. Jingzhou 434020 China \\ 249035829@qq.com
}

\begin{abstract}
Keywords: High level; Private University; Ivy League College; Content of Extracurricular Moral Education
\end{abstract}

\begin{abstract}
In order to draw lessons from the extracurricular moral education of Ivy League schools in the United States, literature research and comparative research methods were used to explore the contents of extracurricular moral education in Ivy League schools. The study found that the Ivy League school is a typical world-class high-level private university. The coalition schools not only attach importance to the improvement of students' knowledge and ability, but also pay attention to the shaping of students' moral character, especially the extracurricular shaping and cultivation of students' moral character. The study concludes that the content of extracurricular moral education in the Ivy League schools is mainly to cultivate the basic moral character of the desire for freedom and the pursuit of truth. It is based on the premise of nourishing enthusiasm for public welfare and serving the country's social morality so as to create independent thinking and advocating practice learning. Character-based. This conclusion has important enlightenment and reference value for Chinese private universities.

The "Ivy League" school is a typical representative of the earliest high-level private universities in the United States. Although the "Ivy League" school did not specifically set up courses named after "moral education," the social studies courses they generally set up, including Western thought history, American modern civilization, politics, philosophy, and economics, are all very colorful in moral education. Strong course. In addition to these tangible classroom education, the Allied University attaches great importance to the cultivation and cultivation of moral qualities of students. The contents of extracurricular moral education mainly include the following aspects.
\end{abstract}

\section{Aiming at Cultivating the Fundamental Virtues of Yearning for Freedom and Pursuing Truth}

The U.S. "Ivy League" allies have distinctive moral education ideas. One of the core of these ideas is to cultivate the teachers and students' aspiration for freedom and the pursuit of the basic qualities of the truth. This is also the spirit advocated by the American Association of Professors. The famous "Three A Principles" (1) elaborated by the Association of Professors at the National University of the United States in the early 20th century embodies the United States' higher education thinking. The "Three A Principles" are "Academic freedom; Academic Autonomy; Academic Neutrality". Harvard University has always put this concept into school education and management, and it has been directly solidified in school school badges. Harvard's school motto is "Let Plato be your friend, and Aristotle, but more let your friend be truth." The instructor must be as free as Plato and Aristotle, advocating academics and pursuing truth. (2). In the course of more than 300 years of running a school, Harvard's teachers and students are committed to spreading truth and recourse to the truth. They break the rules in scientific research, make new innovations, create inventions, and pursue higher education, scientific research, and social development in the United States. It has made world-renowned contributions. In order to pursue truth and be pragmatic, Harvard University did not hesitate to give a degree to the President of the United States. This incident was popularized by the international community. It was in 1986 that Harvard University celebrated its 350th anniversary. The school intends to invite the then US President Reagan to attend the ceremony. President Reagan readily accepted the invitation and proposed that he be best given an honorary doctorate at the ceremony. However, when the Harvard Board of Directors discussed the matter, they had different opinions. When there was a dispute and it was difficult to finalize, the teachers and students of the 
school were widely consulted. As a result, most teachers and students believe that the highest academic institution can award a doctorate to a film actor. In the end, the matter was over. Reagan didn't get a degree, and he didn't come to Harvard to celebrate (3). This is what happened at Harvard, and at Yale. When President George W. Bush was invited back to his alma mater to receive a doctorate in honor of law in May 2001, professors and students at Yale University also publicly expressed their opposition, and 200 professors collectively refused to attend the graduation ceremony attended by Bush. They believe that according to Bush's performance and performance at school that year, he was not qualified to accept a doctoral honorary title (4). This true spirit is also a manifestation of Yale's philosophy. Yale University has long insisted on leading teachers and students to pursue "truth and light", pursue excellence and contributions, pay attention to independent school running, eliminate external interference, and allow teachers and students to concentrate on learning and research, even if it is the loss of government funds. For example, during the Vietnam War in the 1960s, the U.S. government ordered that any student who claims to oppose war on moral or religious grounds will not be allowed to receive scholarships. At that time, many prestigious schools in the United States had implemented government directives. Yale University, in spite of its consistent style of independent schooling, ignored government decrees, and still used academic performance as the sole criterion for granting scholarships (5). As a result, Yale lost a large amount of federal funds, causing the school economy to be in trouble once. Even so, the belief in Yale's independent governance remains unchanged and admirable. Brown University also places special emphasis on and respect for freedom. It treats students as equal to adults. Since its establishment 300 years ago, it has always insisted that students choose their own majors and courses. It aims to train students to acquire their own judgments and decisions as soon as possible. After students enroll in the school, the school only publishes the course catalog, introduction, explains the course selection method, and gives the students a two-week trial period. After the audition, the students determine the courses chosen for the semester according to their preferences. In the course of free electives, students will gradually clarify or form their own interests, and at the end of the second academic year, they will establish their own professional direction. Brown's teaching only requires that students obtain a grade higher than $\mathrm{C}$ in at least 30 classes before graduation, and they can graduate with a certain degree of writing skills (6). Students only need to take 4 courses a semester, and failing grades do not appear on the transcripts. To help students lay a broad knowledge base, Brown University only awarded undergraduate graduates Bachelor of Arts or Bachelor of Science, if students are willing to liberal arts and culture, you can study for five years, to meet the corresponding requirements, to give a dual Bachelor of Arts and Sciences.

\section{The Premise is to Nourish Enthusiastic Public Welfare and Serve the Country's Social Ethics.}

The "Ivy League" school has trained some American presidents, parliaments and various government officials. Harvard University has 8 American Presidents, 10 Chief Justices and countless members of Parliament and Ministers; Yale University has 5 American Presidents; Princeton University has 2 American Presidents and 12 American Supreme Court Justices. More than 1,000 MPs and senior officials of the federal government; Columbia University created 5 American founding fathers, and also trained 4 U.S. presidents, 34 heads of state and heads of state, and 10 U.S. Supreme Court justices. The important reason why the "Ivy League" AU school can create presidents and government officials is that all schools attach great importance to long-term adherence to the teachers' and students' enthusiasm for charity, serve the country, and serve the society. This encourages students to study science. At the same time as cultural knowledge, we use the knowledge we learn to serve the society, participate in social activities, solve social problems, and serve as social concerns, defenders, and builders. In 1990, the United States promulgated the "National Comprehensive Practice Activity Act" and "National Service Hope Act" (7). It established the important position of a comprehensive practical social service activity course in the form of law. The US education community began to teach students about social ethics from the beginning of the elementary school. In addition to the legal courses, the students in the middle school stage are 
encouraged to instill the citizen's rights and obligations and the concept of observing the law. At the same time, students are required to participate in community activities to provide services for social welfare activities. For example, organize students to go to hospitals, orphanages, and welfare centers to help the widows and the disabled. They use wheelchairs to push old people to the park; chat with orphans; chat to the public library to organize books; and participate in distribution to the homeless free of charge. Food and so on. The U.S. high school student handbook has a special page that records volunteer activities, which is also a prerequisite for applying for university in the United States (8). After students participate in community service activities, the unit receiving the service must sign opinions in the student handbook, including the time and performance of the students' participation in the volunteer activities. These records are deposited in the student's file as one of the assessment criteria for middle school students to apply for the university. Some states have stipulated that social services for middle school students must meet the required amount of practice; otherwise, no matter how good their academic performance is, they will not be able to graduate. When new students are admitted to the university, middle school students applying for admission must provide records of their participation in community services. Recorded students will be admitted preferentially. Students who do not have community service records will not be admitted if their academic performance is better. U.S. universities believe that a student who does not participate in social services is not sound in moral character and therefore is not worthy of training at school. Therefore, the more brand-name universities require higher student community services, the more they value the real performance of student community services. For example, Harvard University, Yale University, Stanford University, etc., all regard the performance of community services as a condition for strict assessment. This kind of community service system is actually a mandatory requirement for middle school students to participate in community service activities, allowing students to experience society in their activities, to understand society, to learn to interact with people, and to develop their sympathies, tolerance, public welfare, and social communication skills. Help students gradually develop the quality of serving the public and serving the country. Due to the constraints of the legal system and the attention of the school, the United States has 100 million people each year participating in various forms of voluntary service activities, of which $85 \%$ are young students. Harvard University's influential Phillips Brooks Alumni Association is a social service agency run by students. The association has 35 service programs, such as helping disabled children, helping homeless people, and so on. More than 1,000 students act as volunteers in this institution (9).

Princeton University models social services as a campus spirit. Students can participate in the construction of school public projects. They can also participate in voluntary activities in non-profit organizations or governments and international organizations. The advantage of Princeton University education is to promote the concept of the founders, to serve the individuals, the government, and the world, to firmly pursue the belief in knowledge freedom, and to cultivate qualities that have been ignored, such as integrity, glory, fairness, and courage. The most important of these qualities is service, that is, serving the country and the world. Princeton University clearly stressed: "No matter where you are or in any position, you must develop and cherish the spirit of charity and serve others." (10) People who have been to Princeton University may find that in the middle of a meadow in front of Nassau Hall stands There is a bronze medal engraved with "In the Nation's Service, In the Service of All Nations." This instruction fully reflects the dedication of Princeton University and the "Ivy League" schools in cultivating students' social service awareness, and also reflects the vision of the country's vision, world-mindedness, innovative quality, and leadership skills of the "Ivy League" schools. This is also the reason why the "Ivy League" affiliate school can create many American presidents and countless members of parliament and senior government officials.

\section{Learning Character of Independent Thinking and Advocating Practice}

In the process of personnel training, the "Ivy League" school attaches great importance to creating 
the spirit and ability of students to combine theory with reality and be good at independent thinking. Harvard professors consciously put the principle of independent thinking in teaching practice, established an equal and free partnership with students, and focused on creating an equitable, relaxed and unrestrained atmosphere in the classroom in order to stimulate students' enthusiasm and initiative in independent thinking and bold exploration. . For this reason, teachers prefer to spend a lot of time organizing seminars, group counseling, experimental design, and data enquiries.

In order to cultivate students with independent thinking and creative spirit, Harvard University attaches great importance to the entrance of good students. When selecting students, the "Commitment" is highly valued. They believe that "persistence" is the success leader. Although all of the successful individuals have different family backgrounds, personalities, temperaments, conversations, and fields, they all have one common characteristic, namely, "persistence." Therefore, Harvard University's enrollment, whenever the principal meets the applicants for interview, must ask the students to give an example of what they have done in the past to determine whether they have dedication or not. .

Harvard Business School, in order to implement the teaching principle of integrating theory with practice, established and persisted in the case teaching method for a long time. This is to bring practical problems encountered by business enterprises into classroom analysis and debate. Students must study at least 800 cases in 2 years. The learning time for each case takes 12 to 18 hours. In the process of learning, students need to play a variety of roles and participate in thinking and debate according to their role. This kind of learning aims to train students' agile and sensible thinking ability, fast and smooth verbal communication skills, temper students' stamina and perseverance, and train students' good psychological qualities. In case teaching, the teacher's guidance to students is constantly questioning and refuting, and the speed of questioning and refutation is extremely rapid. Students are required to be able to respond to changes quickly, but also to be logically rigorous and impeccable. Otherwise, they will inspire more. Related issues. This kind of debate-like case teaching encourages students to read extensively, so that they have deep background knowledge and solid professional foundation, know how to use the knowledge they learned to serve the community, and solve practical problems in social activities.

Princeton University places special emphasis on cultivating students' rigorous scholarship, meticulous study style, and independent research capabilities. The school implements a mentoring system. Every week, students participate in a small class of 10 to 15 students. The professor or an assistant professor takes the students to review and summarize the lessons they have learned in the past week, guiding them to think comprehensively and sum up. In order to cultivate students' research ability, Princeton University requires undergraduates to do independent research work. Students need to write "third-grade papers" under the guidance of professors in the third grade, and fourth-grade students must write dissertations. In 1893, Princeton University introduced the "faithfulness" system, requiring students to be honest and trustworthy in their academic affairs and to abide by "honorary regulations" (11). That is, students are required to write a written guarantee to ensure that all their written assignments and test papers completed during their study activities are neither plagiarized nor in violation of other ethical norms. They are guaranteed to abide by the "honorary rules" and they also supervise other students in common. comply with. Students who violate the "honorary regulations" will be severely punished. They will be arrested once for one year and will be expelled from school for the second time. After implementing the "honorary regulations," none of the Princeton University's examinations had inspectors. The "honorary regulations" have effectively promoted students' moral cultivation and created a strong style of honesty. They have earned Princeton University a reputation as a society.

Brown University attaches great importance to the cultivation of students' independence spirit and adaptability, and firstly admits good admissions. When enrolling new students, it pays attention to whether students have independent spirit and whether they can adapt to the university's intense and stressful first-year life. In order to attract high-quality students, the school dispatches people to various high schools each year to identify the right candidates. The focus is on selecting the best students in the United States or students who have excellent SAT and high school scores in the top 
ten of the school.

\section{References}

[1][2][3][4][5][6]Y.j.Li and other editors. Into the United States Ivy. Beijing, Mechanical Industry Press, 2010,pp.10-11,32,44,64,66,136.

[7] https://baike.baidu.com/item/

[8] Y. Gu Volunteer in the United States. Secondary school students, December 1, 2006.

[9] L.J.Zhuang compiles. Princeton University Tillman: Aiming for the future, dare to be the first. World Education Information, 2013, Issue 13.

[10]Q.Z. Li Research on Moral Education Functions of American University Schools. Beijing Education, 2011 pp.78-80.

[11] Y.J.Li etc. Approaching the United States, "Ivy." Mechanical Industry Press, January 2010, first edition, p. 86. 